УДК 93/94

\title{
ИСТОРИЧЕСКОЕ ЗНАЧЕНИЕ ПОБЕДЫ СОВЕТСКИХ ВОЙСК В СТАЛИНГРАДСКОЙ БИТВЕ
}

\author{
Николаева Наталия Руслановна
}

студент

Научный руководитель: Исакиева Зулай Сулимовна кандидат исторических наук, доцент кафедры истории

ФГБОУ ВО «Чеченский государственный педагогический университет»

Аннотация: в статье рассматриваются вопросы значимости Сталинградской битвы в обеспечении победы советской армии в ходе Великой Отечественной войны. Победа в Сталинградской битве стала примером стойкости, терпения, непобедимости духа советского народа, послужила своеобразным моральным переломом и укрепила веру в окончательный разгром агрессора. Сталинградское сражение имело решающее значение не только для хода войны на советско-германском фронте, но и для изменения соотношения сил в Европе.

Ключевые слова: Великая Отечественная война, советско-германский фронт, Сталинград, сражение, победа, героизм.

\section{THE HISTORICAL SIGNIFICANCE OF THE VICTORY OF SOVIET TROOPS IN THE BATTLE OF STALINGRAD}

Nikolaeva N.R. Scientific supervisor: Isakieva Zulai Sulimovna

\begin{abstract}
Battle of Stalingrad in ensuring the victory of the Soviet army during the Great Patriotic War. The victory in the Battle of Stalingrad became an example of mass fortitude, patience, invincibility of the spirit of the Soviet people, served as a kind of moral turning point and strengthened faith in the final defeat of the aggressor. The Battle of Stalingrad was crucial not only for the course of the war on the Soviet-German front, but also for changing the balance of forces in Europe.

Key words: Great Patriotic War, Soviet-German front, Stalingrad, battle, victory, heroism.
\end{abstract}


В наше время не только историки и публицисты, но и граждане России все чаще возвращаются к трагическим событиям Великой Отечественной войны, чтобы извлечь необходимые уроки и сделать правильные выводы для обеспечения безопасности современных условиях. Анализ войны предполагает ее трактовку как особого состояния государства и общества. Она полностью меняет образ жизни людей, систему их приоритетов и жизненных установок. Война советского народа с нацисткой Германией была Отечественной войной против агрессора, что необходимо отметить как для патриотического воспитания подрастающего поколения, так и для утверждения исторической правды.

Для граждан Советского Союза эта война была не на жизнь, а на смерть, для немцев же она была войной, направленной на уничтожение нашего государства [1, с. 40].

Начиная войну против СССР, Гитлер делал ставку на молниеносную войну - «блицкриг», как это было со странами Европы, однако расчет этот провалился, и война затянулась на несколько лет. В ней были тяжелые поражения, потери, неимоверные трудности в тылу и на фронте, но были и прорывы, контрнаступления, великие сражения, одно из них Сталинградское сражение. Так, с 17 июля 1942г. по 2 февраля1943 г. на бескрайней степи между Доном и Волгой протяженностью 100 тыс. кв. км развернулось грандиозное сражение. В историю XX в. Сталинградское сражение вошло как самое крупное по масштабам и последствиям сражение всей Второй мировой войны. В битве за Сталинград участвовали более 2 миллионов человек. Германское командование на сталинградском направлении сосредоточило более 1 миллиона солдат, обладавших многочисленной военной техникой: более 10000 орудий и миномётов, 675 танков, более 1200 самолётов. На Сталинградском, Донском и Юго-западном фронтах советская армия насчитывала более 1 миллиона человек и имела 15500 орудий и минометов, 1460 танков, 1350 боевых самолётов [2, с.138].

Важную роль в достижении победы, наряду с такими факторами, как полководческое искусство, вооружение, техническое оснащение играло моральное состояние народа, армии и сила духа. Именно здесь необходимо искать ключ к пониманию причин и истоков победы советской армии в Сталинградской битве.

Сталинградская битва является непревзойденным примером мужества, стойкости, патриотизма и отваги советской армии. Высокие духовные качества народа в Сталинградском сражении-это результат всего советского 
образа и уклада жизни страны, итог воспитательной работы в войсках армии. Неоценимое значение имело обеспечение фронта техникой и боеприпасами. Были проложены дополнительные железнодорожные пути к Волге. На каждого солдата работали по 7 человек в тылу [3, с. 282]

В обороне Сталинграда, героически сражались бойцы, призванные со всей страны, в том числе и из Чечено-Ингушетии: М. Баймурадов, Д. Исаев, Я. Тасуев, Умаров, Н. Атаев, Л. Завраев, Я. Насаев, С. Эсмурзаев, М. Исаев, $\mathrm{X}$. Нурадилов, удостоенные впоследствии медалями и орденами [4, л. 198, 201]. «В ходе Сталинградской битвы 12 сентября 1942 года в последнем бою у поселка Серафимович командир пулеметного взвода Х. Нурадилов был ранен, но, несмотря на ранение, смог уничтожить 250 врагов и 2 пулемета. Ханпаша Нурадилов, уничтоживший до 920 фашистов, скончался от полученных ран по дороге в медсанчасть. 31 марта 1943 г. Указом Президиума ВС СССР Х. Н. Нурадилову посмертно присвоено звание Героя Советского Союза» [5,д.470].

«Ожесточенные бои на Сталинградском фронте вел 255-й отдельный Чечено-Ингушский кавалерийский полк под командованием Мовлида Алероевича Висаитова, включенный в опергруппу генерала В.И. Чуйкова в составе 64-ой армии генерал - майора М. С. Шумилова. В декабре 1942 года М. Висаитов был награжден медалью «За оборону Сталинграда». 6 ноября 1943 года за мужество, проявленное в Сталинградской битве, М.А. Висаитов был награжден Орденом Красной Звезды» [6,с.71].

В период с 19 ноября 1942 г. до 2 февраля.1943 г германская армия потеряла на полях сражений 140000 солдат. 2 февраля 1943 г. полным разгромом германской армии закончилось Сталинградское сражение, продолжавшееся 200 дней. Поражение гитлеровской армии разрушил миф о непобедимости Германии.

Победа в Сталинградской битве укрепила моральных дух солдат советских войск. «За мужество и героизм, проявленные в Сталинградской битве, 124 воина удостоились звания Героя Советского Союза, 745000 защитников Сталинграда награждены орденами и медалями, более 707000 человек медалями «За оборону Сталинграда», 86 воинских соединений и частей, награждены орденами Ленина, Красного Знамени, Красной Звезды. Сталинград был удостоен звания города-героя» [3]

Таким образом, Сталинградская битва вошла в историю как самое масштабное сражение по своим последствиям и ожесточенности. Победа 
советских войск в этом сражении оказала огромное влияние на дальнейший ход Второй мировой войны, показала союзникам способность СССР победить немецкую армию.

\section{Список литературы}

1. Ахтамзян А.А. Сталинградское сражение в зеркале историографии: 60 лет спустя: Вестник РУДН, сер. Международные отношения, № 1 (3), 2003, C. 38-47

2. История Великой Победы. В 3 томах. Том 2. Изгнание и освобождение /под общей редакцией академика РАН А.В. Торкунова; составитель М.А. Мунтян; Московский государственный институт международных отношений (университет) Министерства иностранных дел Российской Федерации. - Москва: МГИМО - Университет, 2020. - 723 с.

3. Крейс В.В. Сталинградская битва как коренной перелом в отношении духовного фактора победы: Вестник университета, №7, 2014, с. 282-285.- - https://cyberleninka.ru/article/n/stalingradskaya-bitva-kak-korennoyperelom-v-otnoshenii-duhovnogo-faktora-pobedy (дата обращения 12.10.2021)

4. ЦА МО РФ. Ф. 33.Оп. 793756. Д. 34. Л. 198-201

5. , ЦА МО РФ Ф. 33.Оп. Д. 470. № записи 18460181

6. Исакиева 3.С., Кадырова Т.У. К 75 летию победы в Великой Отечественной войне: чеченцы в крупнейших сражениях ВОВ//Международный научно-исследовательский журнал № 11 (101) Часть 3. Ноябрь 2020 C.71 https://research-journal.org/wp content/uploads/2020/1 (дата обращения 12.10.2021)

(C) Н.Р. Николаева, 2021 